\title{
Isolation, Characterization and Sensitivity Pattern of Staphylococcus aureus Isolated from Milk Samples in Khartoum State, Sudan
}

\author{
Alla Eldein Ibrahim ${ }^{1}$, Hind A. Elnasri ${ }^{2^{*}}$, Mona A.M. Khaeir ${ }^{3}$ and Adil M.A. Salman ${ }^{1}$ \\ ${ }^{1}$ Department of Preventive Medicine, ${ }^{2}$ Department of Biochemistry and Molecular Biology, \\ ${ }^{3}$ Department of Parasitology, College of Veterinary Medicine, University of Bahri, Sudan \\ *Corresponding author
}

\section{A B S T R A C T}

\begin{tabular}{|l|}
\hline K e y w o r d s \\
Antibiotic \\
sensitivity, Milk, \\
$\begin{array}{l}\text { Staphylococcus } \\
\text { aureus, Sudan }\end{array}$ \\
\hline Article Info \\
\hline $\begin{array}{l}\text { Accepted: } \\
\text { 06 June } 2018 \\
\text { Available Online: } \\
\text { 10 July } 2018\end{array}$ \\
\hline
\end{tabular}

\section{Keywords}

\section{Introduction}

Milk and dairy products constitute the major source of protein for the majority of the population in underdeveloped countries. It is also considered an important health risk factor as it represents a source of some pathogens and drug residues (Bradley, 2002; Ruegg, 2003). Cattle and buffaloes contribute to a large proportion of the total milk production worldwide.

One of the most frequent diseases occurring within lactating animals is mastitis. It is a bacterial disease that causes the infection and
Milk is considered as an important food material for consumers of all age groups. Albeit that, it can harbor a number of pathogens including Staphylococcus aureus which causes a big problems in the dairy industry by affecting milk quality and production. The imprudent use of antibiotics by farmers led to the appearance of resistant bacterial strains. The objective of this study was to isolate, identify Staphylococcus aureus from different farms in Khartoum State and to study its antibiotic sensitivity pattern. A total of 186 milk samples were collected from three areas in Khartoum State. After isolation and identification using Manitol salt agar media and biochemical test, $25.3 \%$ of the samples were tested positive for Staphylococcus aureus. The identification of the isolated bacteria was also confirmed using PCR technique targeting nuc gene. Regarding sensitivity tests, Sulphamethoxazole/Trimethoprim and Ciprofloxacine. 
The Staphylococcus group belongs to the family Staphylococcaceae, which include 47 subspecies. It is a gram-positive bacteria of 0.8-1 $\mathrm{mm}$ in diameter, non-motile nonsporulating and grows in pairs or cluster. Staphylococci present low guanine-cytosine content. These microorganism are mesophiles, with optimum growth temperature between 35 and $37^{\circ} \mathrm{C}$, aerobic or facultative anaerobic and show a respiratory and fermentative metabolism (De Gouveia Caria, 2010).

The major reservoirs of Staphylococcus aureus are infected udders, teat canals, and teat lesions, but these bacteria also have been found on teat skin, muzzles, and nostrils. The bacteria can spread to uninfected quarters by teat cup liners, milkers' hands, wash cloths, and flies (Radostitis et al., 1994; Capurro et al., 1999; Abera et al., 2013).

Staphylococcus aureus is usually identified using traditional biochemical methods '(Tenover et al., 1994). Using molecular biology techniques is nowadays becoming widely used for identification of bacteria in general (Shuiep et al, 2009; Kate, 2012; Preethirani et al., 2015; Jibril et al., 2018).

Antibiotics are commonly used in dairy farms for treatment of mastitis. Recently, the imprudent use of antibiotics led to the appearance of resistant bacteria towards these drugs. This has become a major problem for the treatment of mastitis (Moroni et al., 2004; Tiwari et al., 2013).

In Sudan, Escherichia Coli and Staphylococcus aureus are among the major causes of mastitis in Khartoum State, (Suliman and El Tigani, 2010). Farmers and animal owners are using different types of antibiotic for treatment, among the commonly used drugs are Penicillin, Oxytetracycline, Enrofloxain and Gentamycine.

The aim of this study was to investigate the prevalence of Staphylococcus aureus in dairy cows in Khartoum State. Identification and characterization will be done using biochemical tests and PCR technique using species specific primer. Also to evaluate its antibiotics sensitivity pattern towards three of the commonly used antibiotics.

\section{Materials and Methods}

\section{Study area}

This study was conducted in different areas of Khartoum State - Sudan (Khartoum, Khartoum North and Omdurman). The State is located between 15-36 $\mathrm{N}$ and32-33 E. The attitude is $380 \mathrm{M}$ above sea level. The mean minimum and maximum temperatures range between $18.5-33.9 \mathrm{C}^{\circ}$, respectively.

\section{ii) Sample collection}

A total of 186 milk samples were collected randomly from small scale dairy cows in Khartoum State. The samples were collected aseptically for bacteriological culture. Before sampling the first stream of milk was discarded and the teat ends were disinfected with cotton swabs soaked in $70 \%$ alcohol and allowed to dry. The samples were stored in ice till transported to the laboratory at the College of Veterinary Medicine, University of Bahri for further analysis.

\section{Isolation and Biochemical identification of bacteria}

\section{Isolation of bacteria}

Samples were cultured in Manitol salt agar medium as selective and differential media used for the isolation of Staphylococcus aureus (Finegold, and Sweeney, 1961). The isolates were identified from their morphology and the development of a yellow colour of the red/pink media which indicates a positive result. 


\section{Identification of the bacteria}

Staphylococcus aureus were identified using standard biochemical tests and further confirmed using Polymerase Chain Reaction (PCR) technique.

\section{Biochemical methods}

These included staining with crystal violet, Coagulase test and oxidase tests (Raus and Love, 1983)

\section{Molecular identification}

PCR technique was used. DNA was extracted using Guanidine - Chloride method (modified from Ghatak et al., 2013). Briefly 1-3 colonies of freshly grown culture were mixed with $2 \mathrm{ml}$ of lysis buffer $(50 \mathrm{mM}$ Tris HCL, $25 \mathrm{mM}$ $\mathrm{NaCL}, 25 \mathrm{mM}$ EDTA, 1\% SDS pH 8.0), $5 \mu 1$ of proteinase $\mathrm{K}, 300 \mu \mathrm{l}$ of $\mathrm{NH}_{4}$ Acetate and 2 $\mathrm{ml}$ of guanidine chloride. After incubation overnight at $37^{\circ} \mathrm{C}$, an equal volume of chloroform was added and then centrifuged at $6000 \mathrm{rpm}$ for $5 \mathrm{~min}$. The supernatant was aspirated into a clean tube. Two volumes of cold absolute ethanol were added and kept overnight at $-20^{\circ} \mathrm{C}$. The mixture was centrifuged at 6000rpm for $5 \mathrm{~min}$. The supernatant was discarded then the DNA pellet was washed twice with $70 \%$ ethanol. Dried DNA was re -suspended in $\mathrm{ddH}_{2} \mathrm{O}$ and finally stored at $-20^{\circ} \mathrm{C}$

\section{PCR}

PCR amplification was performed with a pair of primers specific for the gene nuc (genes encoding staphylococcal thermostable nuclease) according to (Preethirani et al., 2015). The following primers were used:

Forward primer: 5'-GCG ATT GAT GGT GAT ACG GTT-3',

Reverse primer: 5'-AGC CAA GCC TTG

\section{ACG AAC TAA AGC-3'}

The PCR protocol was as follows: denaturation at $94^{\circ} \mathrm{C}$, annealing at $55^{\circ} \mathrm{C}$, and extension at $72^{\circ} \mathrm{C}$. The amplification was performed for 35 cycles. The PCR products were visualized by electrophoresis in a $2 \%$ agarose gel.

\section{Susceptibility testing}

The Susceptibility of the isolates against three antibiotics (commonly available drugs used for treatment of mastitis) was tested using agar disc diffusion method (National Committee for Clinical Laboratory Standards, 2001).Isolates that were previously confirmed as Staphylococcus aureus were grown in nutrient agar plate with discs of the tested antibiotics (Penicillin, Combination of Sulphamethoxazole/ Trimethoprim and Ciprofloxacin) placed in the plate. Following $16-18$ hours of aerobic incubation the plates were examined and the diameter of the inhibition zone was measured. The zone diameters were expressed as resistant, intermediate or susceptible according to (Chengappa, 1990; CLSI document 2008).

\section{Results and Discussion}

This study was conducted to investigate the prevalence and antibiotic sensitivity pattern of Staphylococcus aureus in different dairy farms in Khartoum State. A total of 186 milk samples were collected randomly from the three localities.

After growth in the specific media and carrying out the biochemical tests (staining with grams stain, examination for catalase production, oxidase and coagulase tests), 47 $(25.3 \%)$ of the samples were identified as Staphylococcus aureus (Table 1).

Molecular techniques are nowadays regarded as an important tool for identification of 
bacteria. Confirmation of isolates was carried out using PCR. A band size appeared at 186 bp. Similar band size were reported by Preethirani et al., (2015) (Fig. 1).

The percentage of positive samples from different localities was similar as shown in Figure 2.

A similar percentage of isolated bacteria was reported by (Liu et al, 2017; Lili et al., 2018), $26 \%$ and $27 \%$ respectively. The $S$. aureus was detected in $42 \%$ of the total examined milk samples in Egypt (Awad et al., 2017). Lower percentage $(10.16 \%)$ was reported in raw milk samples (Patel et al, 2018). The prevalence rate of Staphylococcus aurues shows variable variation ranging from $40 \%$ down to $10 \%$ (Patel et al., 2018)

Several studies reported that Staphylococcus aureus is the main cause of mastitis (Kerro and Tareke, 2003; Hundera et al., 2005; Mekonnen et al., 2005). A study carried by Abera et al., (2013) in Ethiopia, showed the percentage of Staphylococcus aureus isolated from mastitis cows was $42.1 \%$ which renders it as one of the problem causing in dairy farms,
The variability in prevalence of mastitis results may be affected by different factors such as the season, farm management practices sampling procedures, method of isolation and hygienic practice of milking and selling (Abera et al., 2013; Lili et al., 2016; Patel et al., 2016). An important feature of Staphylococcus aurues is it that it usually survives in the udder resulting in clinical or sub clinical mastitis, but it also can shed into the milk and it becomes a source for infection to other healthy cows during milking- process and become a main source of contaminants (Patel et al., 2018)

Regarding the sensitivity tests, the previously isolated and identified Staphylococcus aureus was tested against three commonly used antibiotics namely Penicillin, Sulpamethoxazole / Trimethoprim and Ciprofloxacine. The isolates were reported as sensitive, intermediate or resistant after measuring the inhibition zone around the specific disc and then classified according to (Chengappa, 1990; CLSI document 2008).All sample (47 isolates) were found to be resistant to Penicillin while susceptible to Sulpamethoxazole /Trimethoprim and Ciprofloxacine (Fig. 3).

Table.1 Biochemical tests for identification of Staphylococcus aureus

\begin{tabular}{|l|l|}
\hline Test & Result \\
\hline Gram stain & Gram positive cocci \\
\hline Catalase & Positive \\
\hline Oxidase & Negative \\
\hline Coagulase & Positive \\
\hline
\end{tabular}


Fig.1 Agarose gel for Staphylococcus aureus specific primer

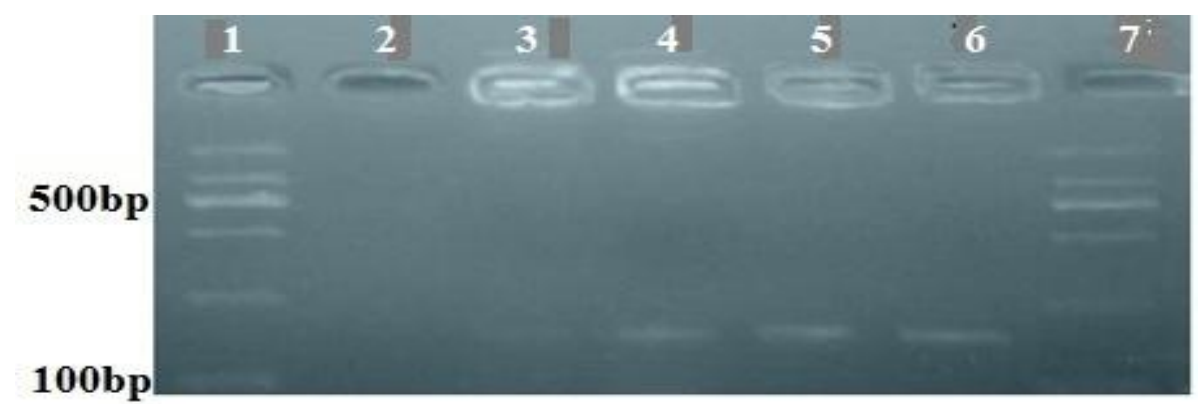

Lane 1 and 7 are DNA marker. Lanes 2 -ve control. Lane 3, 4, 5 and 6 are Staphylococcus aureus 186 bp +ve samples

Fig.2 Percentage of positive samples from the three localities

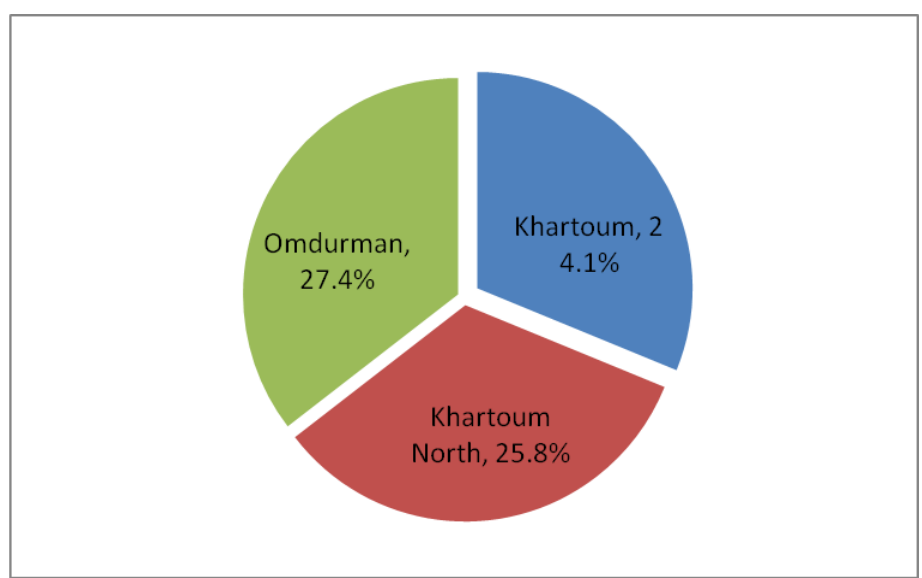

Fig.3 Antibiotic pattern of different isolates

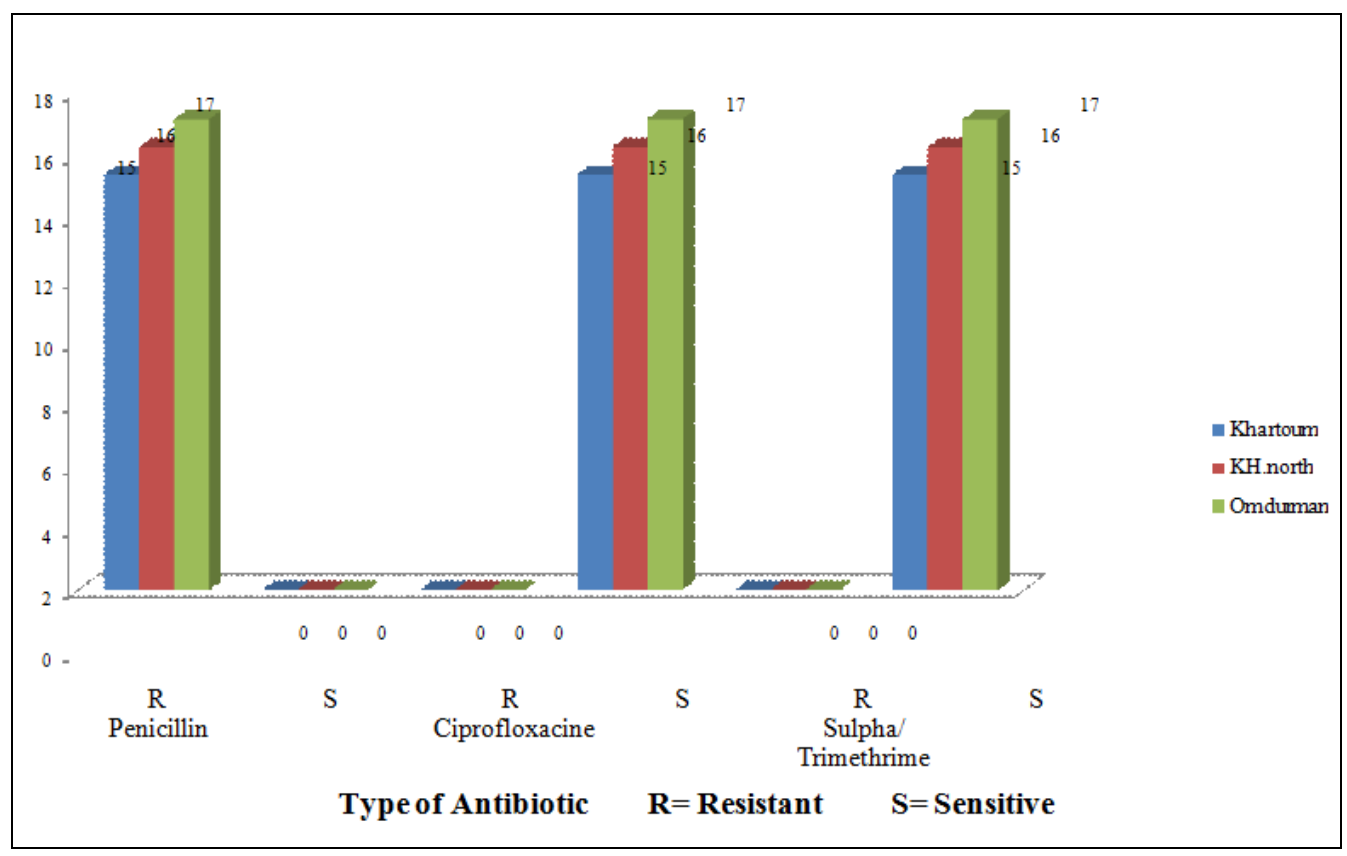


Due to the importance of Staphylococcus aureus in dairy farms, its sensitivity was investigated towards a large number of drugs by different studies (Ahmed, 2003; Abera et al., 2013; Mihael et al., 2010; Lili et al., 2016; Anueyiagu and Isiyaku, 2015). In the study carried by Abera et al., (2013), Staphylococcus aureus was found to be highly susceptible to Chloramphenicol, followed by Gentamycin, Kanamycin and Streptomycin, while in this study the isolated Staphylococcus aureus was found to be susceptible to Sulpamethoxazole / Trimethoprim and Ciprofloxacine. However these isolates were resistant to Penicillin. Similar results for- penicillin resistance - were reported by (Lili et al., 2016; Abera et al., 2013 and Liu et al., 2017) and although the latter study showed that the isolates were also resistant to Trimethoprim/ Sulpamethoxazole followed by amoxicillin.

Another study showed that Staphylococcus aureus isolates were sensitive also to: oxacillin, gentamicin, tylosin, tetracycline, kanamicine, novobiocin, ampicillin and erythromycin while it showed resistance to penicillin, clindamycin, collxacillin and ampicillin (Mihael et al., 2010). The study carried by (Awad et al., 2018) revealed a high resistance of the bacteria against penicillin and ampicillin and a lower resistance was observed against gentamicin, amikacin and ciprofloxacin.

The resistance of Staphylococcus aureus to the penicillin family is believed to be due to production of beta lactamase enzyme which destroys penicillin and related drug family. It is believed that around $50 \%$ of Staphylococcus aurues strains that cause mastitis have the ability to produce beta lactamase (Green and Bradely, 2004).

Another problem with Staphylococcus aureus is that due to its resistance to various to antibiotics, this results in persistent noncurable intra-mammary infection leading to culling of infected animals. It is also causing a problem in human medicine as it has the ability to acquire resistance to the commonly used as well as last resort antimicrobials such as methicillin and vancomycin leading to multidrug-resistant strains (Abdi et al., 2018)

The classic method of classification of bacteria into resistant, intermediate or resistant is now being diverted to an alternative method of "wild type", and "nonwild type" population based on the distribution of inhibition zone diameters (Supre et al., 2014).).

Investigating and identifying the antimicrobial resistance or sensitivity of bacteria towards the drug is a crucial issue as to advice veterinarian or farmers to the suitable treatment in order to minimize the misuse of drugs.

It is important to reduce risk of reintroduction of $S$. agalactiae or the addition of new, potentially more virulent strains of $S$. aureus to the herds through maintaining a closed herd or, at minimum, adhering to clearly defined biosecurity protocols (Keefe, 2012).

In conclusion, this study revealed the high resistance of S. aureus - which was present in all dairy farms investigated - to penicillin. Thus the commonly used Penicillin will be ineffective for treatment of infections caused by this bacteria especially mastitis.

\section{Acknowledgment}

The authors would like to thank all the owners who donated the milk samples and the workers at the laboratory of the College of Veterinary Medicine - University of Bahri, Dr Elmansouri Mahdi and Ms. Fadwa Osman. 


\section{References}

Abdi, R.D, Gillespie B.E, Vaughn J, Merrill C, Headrick S.I, Ensermu DB, D'Souza DH, Agga GE, Almeida RA, Oliver SP, KerroDego O. 2018. Antimicrobial Resistance of Staphylococcus aureus Isolates from Dairy Cows and Genetic Diversity of Resistant Isolates. Foodborne Pathog Dis.doi: $\quad$ 10.1089/fpd.2017.2362. [Epub ahead of print]

Abera, A, Demie,B, K. Aragaw,, F. Regassa, and A. Regassa.2013. Isolation and identification of Staphylococcus aureus from bovine mastitic milk and their drug resistance patterns in Adama town, Ethiopia. African Journal of Dairy Farming and Milk Production Vol. 1 (2), pp. 019-023.

Ahmed E. S. 2003. Prevalence and antimicrobial susceptibility of bacteria isolated from raw milk containing by antibiotics and chemical preservatives in Khartoum state, Sudan. Master Degree. University of Khartoum Sudan

Anueyiagu K. N. and Isiyaku A. W. 2015.Isolation, identification of Staphylococcus aureus from bovine milk and its antibiotics susceptibility. International Journal of Livestock ProductionVol6(6) 74-77

Awad A, Ramadan H, Nasr S, Ateya A, Atwa S. 2017. Genetic Characterization, Antimicrobial Resistance Patterns and Virulence Determinants of Staphylococcus aureus Isolated form Bovine Mastitis. Pak J Biol Sci. 20(6):298-305.

Bradely A.J 2002. Bovine mastitis an evolving disease. Vet. J. 164:116-128

Capurro, A., Concha, C., Nilsson, L. and Ostensson, K. 1999. Identification of coagulase positive Staphylococci isolated rom bovine milk. Acta Vet.
Scand., 40: 315-321

Chengappa M.M. Antimicrobial Agents and Susceptibility Testing.In Carter GR, Cole JR. (Eds.) Diagnostic Procedures in Veterinary Bacteriology and Mycology.5th edition, Academic Press Inc., San Diego, California 1990.

CLSI: Performance standards for antimicrobial susceptibility testing; 18th informational supplement. CLSI document M100-S18. Clinical and Laboratory Standards Institute, Wayne, PA, USA. 2008.

De Gouveia Caria, S. M. D. 2010. Biochemical and Structural studies on the PhoR-PhoB two-component regulatory system from Deinococcus radiodurans. Universidade de Lisboa (Portugal).

Finegold, S. M. and Sweeney, E. E. 1961. New Selective And Differential Medium For Coagulase-Positive Staphylococci Allowing Rapid Growth And Strain Differentiation. Journal Of Bacteriology, 81, 636.

Ghatak, S., Muthukumaran, R. B., Nachimuthu, S. K. 2013. A simple method of genomic DNA extraction from human samples for PCR-RFLP analysis. Journal of biomolecular techniques: JBT, 24, 224.

Green M, Bradely A. 2004. Clinical ForumStaphylococcus aureus mastitis in cattle UK. VET. 9: 4.

Hundera S, Ademe Z, Sintayehu A (2005). Dairy cattle mastitis in and around Sebeta, Ethiopia. Intern. J. Appl. Vet. Med. 3(4): 1525-1530.

Jibril, Mohammed, Michael Henry Ziwa, Yaovi Mahuton Gildas Hounmanou, Adela Kisanga, and Huruma Nelwike Tuntufye. 2018. Molecular Typing and Antimicrobial Susceptibility of Methicillin-Resistant Staphylococcus aureus Isolated from Bovine Milk in 
Tanzania. Int J Microbiol. 428-431.

Keefe G1.2012. Update on control of Staphylococcus aureus and Streptococcus agalactiae for management of mastitis. Vet Clin North Am Food Anim Pract. Jul;28(2):203-16

Kerro OD, Tareke F. 2003. Bovine Mastitis in selected areas of Southern Ethiopia. Trop. Anim. Health Prod. 35: $197-$ 205.

Lili Zhang, Yuchen Li, HongduoBao, Ruicheng Wei, Yan Zhou, Hui Zhang, Ran Wang. 2016. Population structure and antimicrobial profile of Staphylococcus aureus strains associated with bovine mastitis in China. Microbial Pathogenesis 97: 103-109

Liu H, Li S, Meng L, Dong L, Zhao S1, Lan X, Wang J, Zheng N. 2017. Prevalence, antimicrobial susceptibility, and molecular characterization of Staphylococcus aureus isolated from dairy herds in northern China. $J$ Dairy Sci. 100(11):8796-8803.

Mekonnen $\mathrm{H}$, Workineh S, Bayleyegne M, Moges A, Tadele K. 2005.Antimicrobial susceptibility profile of mastitis isolates from cows in three major Ethiopian dairies. Med. Vet. 176(7): 391-394.

Mihael, A, Brinda, V, Herman V., Faur B. 2010. Antimicrobial sensitivity of some Staphylococcus aureus strains from bovine mastitis. Lucrăristiin tificemedicin ăveterinară vol. xliii (1),

Moroni P., Vellere F., Antonini M., Pisoni G., Ruffo G., Carli S. 2004. Antibiotic susceptibility of coagulase-negative staphylococci isolated from goats' milk. Int. J. Antimicrob. Agents. 23:637-640

National Committee for Clinical Laboratory Standards. Performance standards for antimicrobial disc susceptibility tests. 6th ed. Vol. 21 No 1 (M2-A7 and M7A5) and 11th informational supplement 2001 (M100-S11).

Patel, R.K., Kumar, R., Savalia, C.V and. Patel, N.G. 2018 Isolation of Staphylococcus aureus from Raw Cattle Milk and their Drug Resistance Pattern. Int.J.Curr.Microbiol.App.Sci. 7(2): 836-840.

Preethirani,P. L, S,ShrikrishnaIsloor,.V. Sundaresha, K. Nuthanalakshmi, K. Deepthikiran, Akhauri Y. Sinha, D. Rathnamma1, K. NithinPrabhu, R. Sharada, Trilochan K. Mukkur, Nagendra R. Hegde. 2015. Isolation, Biochemical and Molecular Identification, and In-Vitro Antimicrobial Resistance Patterns of Bacteria Isolated from Bubaline Subclinical Mastitis in South India..PLOS ONE | DOI:10.1371/ journal.pone.0142717

Radostitis, OM, Blood DC, Gay CC. 1994. Veterinary Medicine: A text book of the diseases of cattle, sheep, pigs, goats and horses. $8^{\text {th }}$ ed. Bailliere Tindall: London 8: 563-613.

Raus, J. and Love, D. N. 1983. Characterization of coagulase-positive Staphylococcus intermedius and Staphylococcus aureus isolated from veterinary clinical specimens. Journal of clinical microbiology, 18, 789-792.

Ruegg P. L. 2003. Practical food safety interventions for dairy production. J. Dairy Sci., 86: E1-E9.

Shuiep, E.S, . Kanbar, T Eissa, N., Alber, J, Lämmler, C,. Zschöck,, M, El Zubeir I.E.M., Weiss, R.2009 Phenotypic and genotypic characterization of Staphylococcus aureus isolated from raw camel milk samples. Research in Veterinary Science 86 211-215

Suliman, A. M. and El Tigani Mohamed, T. 2010. Factors determining the load of 
Staphylococci species from raw bovine milk in Khartoum State, Khartoum North, Sudan. Journal of Cell and Animal Biology, 4, 019-024.

Supre, K., Lommelen,K; and L. De Meulemeester, L. 2014 Antimicrobial susceptibility and distribution of inhibition zone diameters of bovine mastitis pathogens in Flanders, Belgium Veterinary Microbiology. 171 (2014) 374-381

Tenover, F. C., Arbeit, R., Archer, G., Biddle, J., Byrne, S., Goering, R., Hancock,
G., Hébert, G. A., Hill, B. and Hollis, R. 1994. Comparison of traditional and molecular methods of typing isolates of Staphylococcus aureus. Journal of clinical microbiology, 32, 407-415.

Tiwari JG, Babra C, Tiwari HK, Williams V, De Wet S, Gibson J, et al.2013. Trends in therapeutic and prevention strategies for management of bovine mastitis: an overview. $J$ Vaccin Vaccination. 2013; 4: 1-11.

\section{How to cite this article:}

Alla Eldein Ibrahim, Hind A. Elnasri, Mona A.M. Khaeir and Adil M.A. Salman. 2018. Isolation, Characterization and Sensitivity Pattern of Staphylococcus aureus Isolated from Milk Samples in Khartoum State-Sudan. Int.J.Curr.Microbiol.App.Sci. 7(07): 592-600. doi: https://doi.org/10.20546/ijcmas.2018.707.072 